\title{
PERAN DAN KOMPETENSI GURU DALAM E-LEARNING
}

\author{
Endang Nugraheni (heni@mail.ut.ac.id) \\ FMIPA Universitas Terbuka \\ Jalan Cabe Raya, Pondok Cabe, Tangerang Selatan
}

\begin{abstract}
E-learning has been growing rapidly despite its pros and cons. Good e-learning is based on principles and pedagogy similar to other type of learning. Align with the shift of educational paradigm from teacher-centered to student-centered, sooner or later teachers should adapt themselves to the new roles. This article discusses teachers' roles and competencies related to e-learning.
\end{abstract}

Key words: competencies, e-learning, pedagogy, teacher's roles

Saat ini perkembangan teknologi informasi dan komunikasi (TIK) telah mempengaruhi berbagai aspek kehidupan manusia, termasuk aspek pendidikan. Dengan perkembangan TIK telah lahir pendekatan baru dalam belajar mengajar yang lazim disebut sebagai electronic learning (e-learning). Namun demikian, telah banyak pula terjadi kesalahpahaman tentang elearning sehingga menimbulkan pro dan kontra atas penerapannya di dunia pendidikan. Banyak pendidik berpendapat bahwa e-learning adalah pendidikan melalui internet semata yang mengandalkan penyampaian pengetahuan dalam bentuk teks yang statis pada layar komputer. Sebagian lainnya mungkin memiliki gambaran tentang lalu lalang informasi yang dangkal dalam bentuk chating sebagaimana yang dilakukan kalangan remaja yang saling mengirim pesan singkat melalui internet.

Pemahaman yang kurang kontekstual dan pengalaman buruk yang didapatkan mungkin menjadi penyebab keengganan dalam menerima e-learning sebagai suatu pendekatan belajar mengajar yang bermakna. Tidak mustahil ada e-learning yang terlaksana secara tidak baik, namun e-learning ada juga yang terlaksana secara baik. E-learning yang baik mengakomodasi pedagogi yang sesuai dan dilengkapi dengan teknologi yang mendukung.

Agar tidak menimbulkan salah paham maka konsep tentang e-learning harus dicermati dan selalu dikaji karena dengan perkembangan TIK yang demikian pesat tidak mustahil pula akan menyebabkan pergeseran konsep dan definisi e-learning. Selain itu perlu ditelaah pula manfaat e-learning baik bagi guru, siswa, maupun kegiatan belajar secara menyeluruh. Manfaat tersebut haruslah nyata dan dapat dibenarkan, terutama dari aspek pedagogi.

Dalam dunia pendidikan telah terjadi pergeseran pusat pembelajaran. Pembelajaran yang secara konvensional berpusat pada guru, semakin lama bergeser kepada pembelajaran yang berpusat pada siswa (O'Neill \& McMahon, 2005). Dengan demikian peran guru dan siswapun menjadi berubah. E-learning memperkuat pergeseran tersebut ke arah pembelajaran yang berpusat pada siswa. Guru harus mempersiapkan diri dan beradaptasi dengan baik terhadap perubahan peran tersebut sehingga visi misi pembelajaran tetap dapat terlaksana dengan baik. Artikel ini terutama akan menekankan pembahasan pada bagaimana peran guru dan kompetensi apa yang semestinya dikuasai oleh guru agar mampu menerapkan e-learning.

\section{HAKIKAT E-LEARNING}

Electronic learning (E-learning) adalah istilah bagi semua bentuk proses pembelajaran yang didukung oleh teknologi. Seringkali media pembelajaran yang digunakan adalah teknologi 
komputer atau teknologi digital. Istilah e-learning seringkali digunakan untuk memaknai kegiatan yang berbeda yang bervariasi cukup luas. Di perusahaan pada umumnya e-learning bermakna sebagai strategi pelatihan bagi karyawan dengan menggunakan media elektronik. Di universitas tatap muka e-learning seringkali bermakna sebagai mata kuliah tertentu yang ditawarkan kepada mahasiswa tanpa harus datang ke kelas melainkan cukup berinteraksi melalui internet.

Dengan berkembangnya e-learning, banyak pula definisi yang dikemukakan yang

semuanya mengacu pada pembelajaran yang diperkaya atau dimediasi oleh TIK.

Menurut Koohang dan Harman (2005, p. 77) e-learning adalah:

"the delivery of education (all activities relevant to instructing, teaching, and

learning) through various electronic media. The electronic medium could be the

Internet, intranets, extranets, satellite TV, video/audio tape, and/or CD ROM."

Tidak dapat dipungkiri bahwa peran TIK dalam penerapan e-learning adalah sangat

besar karena membuka kemungkinan perkembangan dan pilihan lain yang dapat memperkaya

proses belajar tersebut, namun yang tak boleh dilupakan adalah peran penting pedagogi dalam

semua sistem pembelajaran. Nichols (2008) mengemukakan definisi yang mencakup aspek

pedagogi tersebut, sebagai berikut.

"E-learning is pedagogy empowered by digital technology"

(E-learning adalah pedagogi yang diperkuat oleh teknologi digital).

E- learning merupakan kombinasi dari e (electronic) dan learning atau proses

pembelajaran, yang selalu didasarkan pada pedagogi. Teknologi e-learning adalah teknologi

digital yang dalam beberapa aspek memungkinkan dikembangkannya pedagogi baru. Namun demikian pedagogi harus didefinisikan terlebih dahulu, kemudian pedagogi tersebut akan memberi arah pada penerapan teknologi dalam pembelajaran. Agar e-learning dapat berlangsung secara efektif maka pedagogi harus berkombinasi dengan teknologi yang handal dan mudah digunakan. Dengan demikian e-learning harus berbasis kepada pedagogi (Nichols, 2008).

Pembelajaran secara umum, termasuk e-learning dirancang untuk membimbing siswa mendapatkan informasi atau untuk membantu siswa dalam melakukan tugas tertentu.

Pertumbuhan penggunaan e-learning relatif sangat cepat baik di dunia industri maupun di dunia pendidikan. Pada tahun 2007 di Amerika Serikat, pasar e-learning mencapai \$17.5 milyar, yang diperkirakan mencapai $60 \%$ dari seluruh dunia, sedangkan di Eropa mencapai kurang lebih $15 \%$. Sementara itu untuk pasar Asia pertumbuhan diperkirakan mencapai 15 sampai $30 \%$ dari seluruh pasar dunia dalam tahun 2010 (Kopf, 2007). Pertumbuhan yang pesat dapat terjadi karena secara umum e-learning dianggap bermanfaat bagi pengguna.

Manfaat e-learning seperti dijelaskan oleh Jones (2007) adalah terkait dengan kemudahan penggunaannya, penghematan biaya transportasi, kecepatan mengakses informasi, adaptif dan mudah diulang, meningkatkan kerjasama dan interaksi siswa, dan kenyamanan bagi pengguna. Setiap manfaat tersebut dapat diuraikan sebagai berikut.

1. Kemudahan penggunaan

Berkat perkembangan teknologi internet, e-learning menjadi mudah digunakan dalam arti tidak terikat oleh tempat, waktu, dan dapat digunakan oleh siapapun. Siswa, baik yang mengikuti pendidikan formal, maupun pegawai yang mengikuti pelatihan, dapat mengakses e-learning sesuai dengan keinginan mereka.

2. Penghematan biaya transportasi

Karena e-learning dapat dilakukan di rumah, maka ongkos untuk perjalanan dapat dihemat. Berkurangnya perjalanan akan berdampak positif terhadap kelancaran lalu lintas, yang pada akhirnya akan mengurangi pencemaran lingkungan.

3. Kecepatan mengakses informasi 
Dengan perkembangan TIK, informasi yang tersedia juga semakin banyak dan semakin mudah diakses. Secara online informasi terbaru dapat tersebar dan diketahui secara cepat. Permasalahannya bukan lagi pada bagaimana mendapatkan informasi baru melainkan pada bagaimana memilih informasi yang tepat dan akurat.

4. Adaptif dan mudah diulang

E-learning juga memberikan ruang yang lebih luas terhadap perbedaan gaya belajar individu.

Bahkan untuk e-learning yang bersifat interaktif dan adaptif, kegiatan belajar dapat disesuaikan dengan tingkat pengetahuan dan penguasaan awal siswa, sehingga belajar menjadi sesuai kebutuhan siswa. Selain itu karena bahan ajar dapat disimpan maka proses belajar dapat diulang-ulang sesuai dengan kebutuhan siswa. Siswa dapat mengendalikan kegiatan belajarnya sendiri. Dengan kemudahan tersebut, kasus putus belajar diharapkan menjadi menurun.

5. Meningkatkan kerjasama dan interaksi

Jones (2007), menerangkan, e-learning yang diselenggarakan secara benar juga dapat meningkatkan interaksi antara guru dan siswa, antara rekan dan siswa, dan interaksi dalam kelompok yang lebih kecil. Guru tidak memonopoli komunikasi, dan kepuasan siswa atas interaksi ini dapat meningkat.

6. Kenyamanan dan rasa aman

Siswa yang mengikuti e-learning akan terjun ke dalam dunia maya internet, yang bagi sebagian besar orang merupakan lingkungan belajar yang aman dan nyaman karena bebas berpendapat tanpa harus menunjukkan identitas diri yang sebenarnya. Siswa menjadi tidak takut melakukan kesalahan, tidak takut diperolok, tidak terlalu terintimidasi oleh sosok guru, dan dapat mengurangi sifat pemalu. Bagi sebagian besar tipe siswa tersebut, e-learning menjadi lebih nyaman dibandingkan kelas tatap muka.

Kegiatan e-learning memiliki jangkauan yang cukup luas, mulai dari diskusi online, memanfaatkan bahan di web dalam bentuk teks sederhana, video digital, sampai dengan adaptive learning, yaitu suatu bentuk kegiatan belajar yang interaktif dan adaptif sesuai dengan kebutuhan siswa. Berbagai pilihan yang tersedia tersebut dapat dimanfaatkan oleh siswa untuk mencapai sasaran belajar sebagaimana sasaran belajar bagi kegiatan belajar tatap muka. $E$ learning dapat diterapkan secara berbeda sesuai jenis belajar yang dikehendaki. Sebagai contoh, video dapat digunakan untuk menayangkan sebuah sesi tanya jawab dengan seorang ahli. Video mungkin juga dapat digunakan untuk menunjukkan keterampilan motorik. Diskusi online dapat disusun sedemikian rupa sesuai dengan tujuan pembelajaran yang diinginkan. Prinsip inti pendidikan tidak berubah dengan penerapan e-learning. Teori pembelajaran yang biasa digunakan pada kelas tatap muka dapat diterapkan pula dalam e-learning. Alih-alih mencoba menggantikan teori-teori pendidikan, e-learning menciptakan kemungkinan baru dalam penerapan teori-teori pendidikan.

\section{PERGESERAN PERAN GURU}

Sejak munculnya pendekatan konstruktivisme dalam pendidikan maka proses belajar mengajar yang secara konvensional berpusat pada guru telah bergeser menjadi berpusat pada siswa. Proses pergeseran tersebut tentunya tidak terjadi secara drastis melainkan sedikit demi sedikit dalam suatu kontinum sebagaimana digambarkan oleh O'Neill dan McMahon, (2005). Peran guru bergeser menjadi kolaborator dan fasilitator dalam belajar. Guru membantu siswa mengakses semua sumber belajar yang tersedia dan bukan sebagai satu-satunya sumber belajar.

Perubahan peran guru dari sumber belajar utama menjadi fasilitator atau pendamping tidaklah mudah, sehingga cukup wajar apabila terjadi beberapa resistensi. Menurut Doyle (2006) ada berbagai penyebab resistensi guru, antara lain: bergesernya pusat perhatian; perasaan 
kurang berarti karena hanya sebagai pendamping siswa, sedangkan siswa yang mengontrol seluruh kegiatan belajar; dan sebagian guru akan menganggap bahwa siswa tidak dapat menangani tanggung jawab atas belajarnya sendiri. Pada kenyataannya banyak guru yang tidak mengetahui bagaimana memegang peran yang baru tersebut. Hambatan dalam mengadaptasi peran yang baru tersebut terutama terlihat pada lingkungan pembelajaran tatap muka sehingga perlu dilakukan perubahan secara bertahap (Hall, 2006).

Di lingkungan pembelajaran pada institusi pendikan terbuka dan jarak jauh (PTJJ), perubahan tersebut mau tidak mau diatur oleh sistem. Dalam PTJJ, implementasi pembelajaran yang berpusat pada siswa harus dilakukan sejak awal, yaitu sejak perencanaan kurikulum yang diikuti dengan perancangan pembelajaran dan pengembangan bahan ajar. Disain PTJJ yang terutama difokuskan pada belajar mandiri merupakan implementasi nyata dari pembelajaran berpusat pada siswa. Bahan ajar yang dikembangkan secara terpusat, dapat didisain secara moduler dan mengakomodasi kegiatan belajar mandiri. Bahan ajar, selain yang berupa uraian tercetak, dapat pula dilengkapi dengan berbagai bentuk multimedia, baik yang terintegrasi dengan bahan ajar tercetak maupun sebagai bahan ajar tambahan (Nugraheni, 2007).

Selanjutnya, strategi belajar yang dipilih pada PTJJ lebih banyak berbasis pada siswa, sehingga siswa dituntut untuk aktif belajar mandiri. Inisiatif kerja kelompok hampir sepenuhnya diserahkan kepada siswa. Dalam PTJJ dikenal upaya bantuan belajar dalam bentuk tutorial, baik secara tatap muka maupun berjarak seperti tutorial online dan tutorial tertulis. Pada kegiatan tutorial tersebut guru sepenuhnya bertindak sebagai fasilitator mengingat bahan ajar utama adalah modul tercetak dan multimedia. Dengan demikian, sejak awal peran guru telah didisain sebagai fasilitator atau yang lazim disebut tutor. Dalam sistem tersebut peran guru telah bergeser sesuai dengan tuntutan sistem (Nugraheni, 2007).

\section{PERAN GURU DALAM E-LEARNING}

E-learning telah memperkuat dan mempercepat terjadinya pergeseran peran guru. Peran guru dalam e-learning adalah sebagai disainer instruksional, fasilitator dalam interaksi belajar, dan ahli materi. Peran guru yang utama adalah untuk mendorong proses perkembangan kognitif siswa yang dicapai melalui media komputer yang diharapkan memiliki aksesibilitas dan adaptabilitas yang tinggi (Seok, 2008). Dalam e-learning guru juga dituntut untuk terampil dalam bidang TIK, terutama dalam pembuatan tampilan bahan ajar melalui media.

Peran guru sebagai sumber utama informasi dan pengetahuan, menjadi berkurang jauh dalam era e-learning. Berbagai jenis informasi dan pengetahuan tersedia secara gratis dari internet. Guru harus mengadaptasikan perannya dari sumber atau penguasa ilmu menjadi pembimbing siswa dalam memilih dan menseleksi kegiatan belajar. Peran guru sebagaimana dikemukakan oleh Barajas, Scheuermann dan Kikis (2002) adalah sebagai: siswa, tutor, kolaborator, pengembang materi, peneliti, siswa TIK seumur hidup, dan anggota dari tim pengajar.

1. Peran guru sebagai siswa

Telah menjadi kenyataan bahwa pada era e-learning ada kemungkinan siswa lebih menguasai suatu pengetahuan atau keterampilan tertentu dibanding guru. Dalam keadaan tersebut guru harus bersedia untuk belajar kepada siswa atau belajar bersama-sama siswa. Sebagai contoh, seringkali siswa lebih menguasai aspek teknis penggunaan komputer dibanding guru. Pada kejadian tersebut guru tidak boleh segan untuk belajar dari siswa. Informasi terbaru yang terkait dengan materi maupun perangkat lunak yang dapat diunduh secara bebas dari jaringan internet tersedia dalam jumlah banyak dan selalu berkembang dengan cepat. Hal tersebut menuntut semua pengguna internet, termasuk guru, untuk mampu terus belajar dan mengikuti perkembangan.

2. Peran guru sebagai tutor 
Dibandingkan berbagai peran lainnya, peran guru sebagai tutor adalah yang paling dikenal. Guru sebagai tutor pada umumnya berperan sebagai ahli materi yang memfasilitasi kegiatan belajar, memecahkan permasalahan yang dihadapi siswa, dan memperbarui isi materi belajar. Sebagai tambahan peran guru sebagai tutor juga mencakup peran sebagai model atau pemberi contoh, yaitu dalam hal menstimulasi siswa dengan cara membuat materi atau menciptakan situasi untuk belajar aktif. Tutor juga dapat berfungsi sebagai pelatih, konsultan, dan sebagai penengah apabila terjadi perselisihan pendapat di antara siswa. Tutor juga bertindak sebagai manajer yang mempertemukan berbagai pihak, ataupun hanya mengawasi jalannya kegiatan belajar saja.

3. Peran guru sebagai kolaborator siswa

Beberapa jenis kegiatan belajar yang berbasis TIK menggunakan pembelajaran berbasis projek sebagai pendekatan pedagoginya. Pada kegiatan belajar berbasis projek tersebut, guru berpartisipasi dalam kerjasama dengan siswa sebagai rekan sederajat.

4. Peran guru sebagai pengembang materi

Pada pembelajaran e-learning, seringkali guru juga harus berperan sebagai pengembang materi belajar dalam format elektronik, baik secara langsung maupun sebagai pemberi masukan bagi ahli media profesional. Dalam peran tersebut guru dituntut untuk memiliki keterampilan khusus atau setidak-tidaknya pengetahuan yang mendalam dalam hal TIK yang berkaitan dengan perangkat lunak pengembangan materi ajar.

5. Peran guru sebagai peneliti

Penelitian tindakan kelas merupakan kecenderungan yang populer dan sangat bermanfaat bagi perkembangan profesional guru. Guru berperan sebagai peneliti yang dapat mengevaluasi proses kegiatan belajar untuk dapat merefleksikan dan menginternalisasi inovasi yang terjadi dalam kelas ataupun kelompok belajar. Hasil refleksi dapat digunakan untuk memperbaiki proses belajar dan bahan ajar sesuai dengan kebutuhan siswa, sehingga pada penerapan selanjutnya kualitas e-learning dapat meningkat.

6. Peran guru sebagai siswa TIK

Telah menjadi pengetahuan umum bahwa perkembangan TIK sangat pesat. Untuk mengikuti perkembangan tersebut guru harus selalu belajar seumur hidup tentang dunia TIK. Keterampilan dasar atau kemelekan terhadap TIK merupakan langkah awal bagi perkembangan profesionalitas guru. Guru yang terlibat dalam inovasi yang menggunakan TIK pada umumnya akan mudah pula untuk dilatih kembali dalam bidang pedagogi dan inovasi lainnya.

7. Peran guru sebagai anggota tim pengajar

Pembelajaran yang menerapkan e-learning memiliki kompleksitas yang lebih tinggi baik dalam hal penyediaan bahan ajar maupun dalam penyampaiannya. Dalam hal ini guru jarang bertindak secara individual melainkan saling bekerjasama dengan guru lainnya dalam rangka efisiensi. Dengan demikian guru merupakan anggota dari suatu tim pengajar, yang harus saling mengintegrasikan waktu, tenaga, dan sumber lainnya dengan sesama rekan guru. Tujuh jenis peran yang dikemukakan oleh Barajas et al. (2002) tersebut menuntut kemampuan guru beradaptasi. Adaptasi yang harus dilakukan tidak hanya menyangkut keterampilan, melainkan juga menyangkut sikap. Ternyata dengan e-learning, peran guru tidak berkurang ataupun digeser oleh perangkat TIK, sebagaimana yang banyak ditakutkan, melainkan justru bertambah kompleksitasnya. Guru dituntut untuk dapat selalu menambah pengetahuan dan keterampilannya dan menjadi siswa seumur hidup.

\section{KESIAPAN GURU MENGHADAPI E-LEARNING}

E-learning merupakan konsep yang populer yang ingin diterapkan oleh semua institusi pendidikan dari berbagai tingkatan di seluruh dunia. Banyak yang ingin menerapkannya karena 
memahami jelas manfaatnya sebagai batu loncatan kemajuan yang cepat, namun banyak pula yang ingin menerapkan hanya karena ikut-ikutan, melihatnya sebagai sesuatu yang "trendy", ataupun takut ketinggalan jaman. Apapun alasannya, ternyata tidak mudah untuk serta merta menerapkan e-learning, walaupun pembahasan dan contoh penerapannya telah banyak dipublikasikan dalam satu dekade terkhir ini. Institusi pendidikan yang telah menyampaikan kegiatan pembelajaran bermutu tinggi dengan metode konvensional, tidak otomatis dapat menyampaikan pembelajaran dengan modus e-learning dengan kualitas yang tinggi pula. Diperlukan persiapan matang, adaptasi, dan transisi untuk mengubah pembelajaran konvensional menjadi e-learning.

Langkah awal persiapan yang harus dilakukan tentunya adalah mengetahui kesiapan guru. Menurut fakta, kesiapan tersebut ternyata masih relatif rendah, baik di negara maju maupun negara berkembang. Menurut penelitian di universitas terkemuka di Mesir, hanya $28 \%$ dari dosen merasa memiliki kompetensi e-learning yang baik, dan hanya $16,6 \%$ yang memiliki kemampuan teknis mengembangkan e-learning. Sedangkan yang berkaitan dengan pengalaman, hanya $7,3 \%$ yang merasa memiliki pengalaman cukup, dan hanya sekitar seperempat responden yang pernah menggunakan bahan e-learning untuk perkuliahan mereka (Sadik, 2007). Namun demikian, walaupun kesiapan mengajar dengan e-learning masih relatif kecil, tetapi sikap para dosen tersebut adalah tetap positif terhadap perkembangan dan penerapannya (Sadik, 2007).

Di Indonesia e-learning masih dianggap suatu hal baru sehingga belum banyak publikasi tentang hal tersebut. Menurut penelitian Kuntoro dan Hawamdeh (2003) tentang penerapan elearning di perguruan tinggi di Indonesia, sebagian besar pengembangan masih berada pada taraf awal dan partisipasinya masih rendah, walaupun kualitasnya cukup memadai. Penelitian tersebut juga menyebutkan adanya hambatan penerapan dari segi infrastruktur dan keengganan dosen dalam mengadopsi e-learning, sehingga implementasinya lambat.

Sebelum dapat menerapkan e-learning perlu diketahui hambatan apa saja sebenarnya yang dihadapi. Hambatan yang terjadi dapat bersifat situasional, epistemologik, psikologik, pedagogik, teknik, dan sosial budaya (Berge, 1998). Contoh hambatan tersebut antara lain: kekhawatiran guru untuk digantikan sepenuhnya oleh komputer, kurangnya waktu yang cukup untuk persiapan dan implementasi, banyaknya siswa yang tidak siap untuk belajar mandiri, mahalnya biaya awal untuk mengembangkan e-learning, ketakutan atas semakin tingginya ketergantungan dengan teknologi yang apabila gagal akan merusak seluruh kegiatan belajar, kurangnya pelatihan dan bantuan teknis, serta adanya resistensi terhadap perubahan.

Untuk mengatasi hambatan dan ketidaksiapan guru menerapkan e-learning diperlukan pelatihan dalam kapasitas yang memadai. Apabila dari aspek matapelajaran dan pedagogi, guru telah memiliki latar belakang pengetahuan yang cukup, tidak demikian halnya dengan keterampilan teknis. Banyak guru yang tidak terampil dengan TIK. Selain itu faktor fasilitas yang disediakan institusi dan infrastruktur komunikasi akan berpengaruh besar pula terhadap perkembangan e-learning.

Di samping diperlukannya pelatihan, kesiapan juga dipengaruhi oleh kemampuan adaptasi terhadap peran baru. Sementara itu, kemampuan adaptasi tersebut dipengaruhi oleh sikap dan persepsi guru terhadap e-learning. Dengan demikian dapat dikatakan bahwa masih diperlukan upaya yang cukup panjang untuk dapat menerapkan e-learning. Untuk memulai upaya tersebut, persiapan yang matang, dalam arti terjadwal, terukur, dan spesifik harus dilakukan, misalnya untuk mulai melakukan pelatihan, perlu diketahui terlebih dahulu kompetensi khusus seperti apa yang harus dikuasai guru, agar dapat menyelenggarakan e-learning. 


\section{KOMPETENSI YANG HARUS DIKUASAI GURU DALAM E-LEARNING}

Kompetensi didefinisikan sebagai "seperangkat tindakan cerdas, penuh tanggung jawab, yang dimiliki seseorang sebagai syarat kemampuan untuk mengerjakan tugas-tugas di bidang pekerjaan tertentu" (Keputusan Mendiknas RI No. 045/U/2002). Untuk dapat melakukan pembelajaran secara e-learning, guru harus menguasai prinsip-prinsip e-learning. Selain itu, diperlukan sejumlah kompetensi khusus yang terbagi sesuai proses pembelajaran yaitu: kompetensi untuk mempersiapkan pembelajaran; kompetensi untuk melaksanakan pembelajaran; dan kompetensi pada akhir pembelajaran yang diuraikan sebagai berikut (Queiroz \& Mustaro, 2003).

1. Kompetensi untuk mempersiapkan pembelajaran e-learning Pada saat mempersiapkan pembelajaran e-learning maka kompetensi khusus paling mendasar yang dibutuhkan guru adalah kompetensi untuk mengembangkan silabus elearning secara efektif, yang mencakup pula kemampuan pengorganisasian kelompok belajar, prosedur interaksi kelompok, pembagian tanggung jawab, dan garis besar kegiatan pembelajaran. Kompetensi lain yang berperan penting pula adalah guru memiliki pemahaman yang jelas tentang kebutuhan pembelajaran, kemampuan menyampaikan tujuan pembelajaran, dan mendefinisikan kriteria penilaian dan partisipasi siswa dalam kegiatan belajar. Guru juga harus dapat menjawab pertanyaan dan harapan siswa. Silabus pelajaran harus disusun untuk memberi kerangka kegiatan pembelajaran yang menjadi tujuan namun harus cukup fleksibel untuk memungkinkan terjadinya negosiasi antara guru dan siswa. Semua hal tersebut harus dapat dikomunikasikan dalam bahasa yang jelas, dan dengan kecepatan yang sesuai dengan kondisi siswa.

Guru harus mampu menggunakan teknologi yang dipilih untuk menyampaikan pembelajaran. Teknologi tersebut akan terus dibutuhkan pula ketika kegiatan berlangsung karena merupakan media interaksi antara guru dengan siswa. Selain itu tambahan keterampilan tentang penggunaan beberapa perangkat lunak juga diperlukan, seperti Microsoft Word ${ }^{\mathrm{TM}}$, Excel $^{\mathrm{TM}}$, Adobe Acrobat ${ }^{\mathrm{TM}}$, atau format lainnya. Guru mungkin harus mengembangkan materi dengan perangkat lunak tersebut, demikian pula dengan siswa dalam menjawab atau mengerjakan tugas. Penguasaan jenis TIK ini juga diperlukan ketika guru harus mengunduh materi online dan mengubah atau menerjemahkan untuk bahan ajar. Materi ajar yang tersedia bebas dalam jaringan internet merupakan sumber belajar yang sangat luas, yang dapat dimanfaatkan dalam kegiatan pembelajaran e-learning. Guru dapat membimbing siswa atau bersama siswa mencari informasi dan pengetahuan yang dibutuhkan dari jaringan tersebut. Guru juga dapat berjejaring dengan rekan seprofesi lainnya melalui media tersebut untuk saling berbagi pengalaman dan pengetahuan, yang pada akhirnya dapat bermanfaat pula bagi siswa. Dalam hal penguasaan teknologi ini guru dituntut untuk selalu belajar, memperkaya pengetahuan dan keterampilannya secara terus menerus mengingat kemajuan dalam bidang TIK yang sangat pesat. Sebagai tambahan, dibutuhkan pula kompetensi untuk mempersiapkan siswa mengikuti e-learning dan membuat transisi pembelajaran dapat berjalan dengan mulus.

2. Kompetensi dalam melaksanakan pembelajaran e-learning Setelah pengembangan kurikulum, penulisan atau peracikan bahan ajar, dan sesudah guru atau tutor menguasai teknologi penyampaian materi, bahan e-learning siap untuk diajarkan. Sebelum benar-benar digunakan mungkin ada proses penelaahan materi, yang dapat dilakukan oleh guru lain ataupun oleh siswa, sehingga kesalahan dan kekurangan dapat diperbaiki.

Ketika kegiatan belajar benar-benar dilaksanakan guru harus berpindah peran menjadi fasilitator atau tutor, berfokus tidak hanya pada isi materi melainkan juga pada pembentukan 
komunitas belajar. Pada tahap ini aspek penting yang harus diperhatikan adalah berlangsungnya interaksi antarsiswa, siswa dengan tutor, dan siswa dengan institusi. Salah satu tujuan pembentukan komunitas belajar adalah mendorong belajar kolaboratif dan mengembangkan hubungan kerjasama timbal balik antarsiswa. Pada tahapan ini tutor harus pula memiliki kompetensi untuk membimbing siswa baru yang belum memahami seluk beluk e-learning, mengurangi keraguan dan keengganan siswa, dan membiasakan mereka untuk lancar berinteraksi melalui media. Secara ideal tutor juga harus memiliki hubungan dan kerjasama yang baik dengan siswa, sehingga dapat pula mendorong terjadinya belajar aktif dan membantu mereka untuk mengintegrasikan modus e-learning dengan gaya belajar personal siswa.

Berbasis pada pengelolaan kegiatan belajar yang efektif dan efisien, tutor harus mendorong partisipasi siswa, membuat siswa mau menaati jadwal kerja yang telah disetujui, menekankan pentingnya waktu pengerjaan tugas, mengevaluasi kemajuan belajar siswa, dan memberikan umpan balik yang sesuai. Tutor harus dapat menjadi contoh dalam menjadi peserta e-learning yang baik, dan apabila diperlukan juga menggunakan humor untuk membuat suasana belajar yang menyenangkan.

Berkaitan dengan proses belajar yang dialami siswa, tutor harus dapat mendorong siswa belajar sesuai kebutuhannya, membantu siswa mengidentifikasi kekuatan dan kelemahannya, dan mendorong siswa untuk memperbaiki kelemahannya. Tutor harus memiliki kompetensi untuk mendorong siswa melakukan pemikiran kritis dan membuat refleksi. Siswa juga harus didorong untuk dapat mengambil contoh dari kehidupan nyata dan mengintegrasikannya dengan kelas e-learning. Pendekatan belajar berbasis siswa ini akan menyadarkan siswa bahwa mereka dihargai, dan bahwa informasi dan perspektif mereka dapat membantu orang lain dalam proses belajar. Tutor juga harus mampu menjadi penengah ataupun mengarahkan diskusi kembali ke permasalahan yang seharusnya apabila terjadi penyimpangan dari fokus kegiatan belajar.

Dalam hal interaksi, tutor harus mau menghubungi siswa yang tidak berpartisipasi atau berhenti berpartisipasi (biasanya melalui telepon). Tutor harus selalu mengingat bahwa siswa adalah pribadi nyata yang berinteraksi hanya melalui kata-kata pada layar komputer, serta menghargai masalah pribadi dan kerahasiaan mereka.

3. Kompetensi pada akhir pembelajaran e-learning

Pada akhir kegiatan e-learning tugas tutor masih belum selesai. Tutor masih harus menilai dan mengukur hasil belajar siswa, dan penilaian harus dilakukan secara adil dan didasarkan pada kriteria objektif yang telah ditentukan terlebih dahulu. Selain mengevaluasi kinerja siswa, tutor harus pula mampu mengevaluasi kegiatan belajar secara keseluruhan untuk dapat dilakukan perbaikan bagi kelas berikutnya. Pada akhir kegiatan belajar tersebut tugas tutor juga meliputi masalah teknis administratif, seperti mencatat dan mentransfer nilai mahasiswa ke dalam sistem administrasi sekolah, dan menyusun laporan akhir tentang pelaksanaan kegiatan belajar yang telah terjadi. Kepada siswa tutor juga harus memberikan umpan balik dan catatan atas semua tugas, makalah, dan tes yang pernah dikerjakan siswa. Secara khusus, komentar dan pendapat siswa dapat pula digunakan untuk mengevaluasi kinerja tutor sendiri. Tutor harus terus menghormati privasi individual siswa walaupun kegiatan belajar telah selesai.

\section{PENUTUP}

E-learning merupakan kebutuhan baru dalam dunia pendidikan yang ditandai oleh pertumbuhan yang pesat. E-learning yang berhasil adalah yang didasarkan pada pedagogi sebagaimana kegiatan belajar yang lain. Namun demikian, tidak semua orang yang telah memahami pedagogi serta merta dapat melaksanakan e-learning dengan lancar. Untuk dapat 
melakukan jenis pembelajaran tersebut diperlukan persiapan matang dan langkah yang tepat, yang melibatkan keterampilan baru bagi guru, terutama keterampilan di bidang TIK.

Seiring dengan pergeseran paradigma pendidikan menuju pembelajaran yang berpusat pada siswa, dalam e-learning guru harus mengadaptasikan diri dengan peran baru. Peran tersebut adalah guru sebagai siswa, tutor atau fasilitator, kolaborator siswa, pengembang materi, peneliti, siswa TIK, dan anggota tim pengajar. Perubahan peran tersebut menuntut pula perubahan sikap dan keterampilan, terutama yang berkaitan dengan TIK. Akhirnya untuk dapat melaksanakan e-learning dengan baik guru harus memiliki berbagai kompetensi yang dikelompokkan sesuai dengan proses pembelajaran, yaitu persiapan, pelaksanaan, dan akhir pembelajaran. Akhirnya, untuk mencapai kompetensi tersebut dibutuhkan pelatihan, kesabaran, dan proses belajar yang terus menerus.

\section{REFERENSI}

Barajas, M., Scheuermann F.,\& Kikis, K ( 2002).Is the Role of the Teacher as the "Knowledge Authority" in Danger in an ICT-Learning Setting? This text is a fragment corresponding to chapter 3.1 of the article "Critical indicators of innovative practices in ICT-supported learning", presented at PROMETEUS Conference held in Paris, 29th -30th September 2002. Diambil 5 Maret 2008, dari http://www.elearningeuropa.info/doc.php?lng=1\&id= $580 \&$ doclng $=1 \& p 3=1$

Berge, Z.L. (1998). Barriers To Online Teaching In Post-Secondary Institutions: Can Policy Changes Fix It? Online Journal of Distance Learning Administration, Volume I, Number 2, Summer 1998.

Doyle, T. (2006). The role of the teacher in a learner-centered classroom. Diambil 27 Januari 2007, dari http://www.ferris.edu/htm/s/academics/center/teaching_and_learning_Tips/ Learner-Centered\%20Teaching/RoleofTeacher.htm.

Hall, B. (2006). The nature of "Student-Centred Learning". Diambil 24 November 2006, dari http:// secondlanguagewriting.com/explorations/Archives/2006/Jul/StudentcenteredLearning.ht $\mathrm{ml}$.

Jones, K. L. (2007, June 12). The Advantages of eLearning. Diambil 17 Januari 2008, dari http://ezinearticles.com/?The-Advantages-of-eLearning\&id=603386

Koohang, A. \& Harman, K. (2005). Open source: A metaphor for e-learning. Informing Science: The International Journal of an Emerging Transdiscipline, 8, 75-86. Diambil 37 September 2007, dari http://inform.nu/Articles/Vol8/v8p075-086Kooh.pdf

Kopf, D. (2007). E-learning Market to hit \$52.6B by 2010. The Journal: July 2007.

Kuntoro, R.D. \& Al-Hawamdeh, S. (2003). E-Learning in Higher Educational Institutions in Indonesia. Journal of Information \& Knowledge Management (JIKM). Vol. 2, Issue 4. pp. 361 -374. Diambil 14 Februari 2006, dari http://www.worlscinet.com/jikm/02/0204/ 50219649203000553.html

Nichols, M. (2008). E-learning in context. Diambil 5 Januari 2008 dari Creative Commons Attribution-No derivative works 3.0 New Zealand. http://creativecommons.org/licenses/by$\mathrm{nd} / 3.0 / \mathrm{nz} /$

Nugraheni, E. (2007). Student centered learning dan implikasinya terhadap proses pembelajaran. Jurnal Pendidikan, Volume 8, Nomor 1, Maret 2007, 1-10

O'Neill, G. \& McMahon, T. (2005). Student-centred learning: What does it mean for students and lecturers? Diambil 25 November 2006, dari http://www. aishe.org/readings/20051/oneillmcmahon-Tues_19th_Oct_SCL.html.

Queiroz, V \& Mustaro, P.N. (2003). Roles and competencias of online teachers. The Internet TESL Journal, Vol. IX, No. 7, July 2003. Diambil 10 Februari 2008, dari http://iteslj.org/Articles/Queiroz-OnlineTeachers.html 
Sadik, A. (2007). The Readiness of Faculty Members to Develop and Implement E-Learning: The Case of an Egyptian University.International Journal on ELearning. Norfolk: 2007. Vol. 6 , Iss. 3; pg. 433, 21 pgs

Seok, S. (2008). Teaching Aspects of E-learning . International Journal on ELearning. Norfolk: 2008. Vol. 7 , Iss. 4 ; pg. 725,17 pgs 